\title{
A TÁRSAS HELYZETBEN TAPASZTALT FLOW-ÉLMÉNY KAPCSOLATA A BOLDOGSÁGORIENTÁCIÓKKAL
}

\author{
MAGYARÓDI TÍMEA ${ }^{1}$ \\ ${ }^{1}$ Eötvös Loránd Tudományegyetem Pszichológiai Intézet \\ E-mail: magyarodi.timea@ppk.elte.hu
}

Beérkezett: 2019. szeptember 30. - Elfogadva: 2019. október 22.

Háttér és célkitûzések: Az áramlatélménnyel teli, elkötelezett élet a boldogságorientációk egyikének tekinthetố, a teljes élet része, az élvezetes és jelentésteli élet mellett. Társas helyzetben való megélése miatt a jóllét növelésének egyik eszköze is lehet. A társas helyzetben tapasztalt flow összefüggéseit a jóllét különbözô dimenzióival eddig nem vizsgálták, holott a társas kapcsolatok jóllétnövelő szerepét több koncepció hangsúlyozza: jelen vizsgálat célja a flow-élmény társas helyzetben való átélésének boldogságorientációkhoz kapcsolódásának feltárása.

Módszer: Online kérdốives módszerrel lebonyolított kutatásunkban 1060 fố, 18 éven felüli válaszadó vett részt, életkori átlag (szórás) = 26,67(10,76). A kérdốveket anonim módon töltötték ki: Általános Flow Leírás, Általános Flow Leírás Társas Interakciókban, Flow Állapot Kérdôiv, Flow Szinkronizáció Kérdôiv, Boldogságorientáció skála.

Eredmények: K-központú klaszterelemzéssel az élvezetes és jelentésteli boldogságorientációt leiró változókkal a résztvevókbôl négy csoportot alkottunk: jelentésteli, örömteli boldogságorientációval jellemezhetố személyek, üres, valamint teljes életet élô személyek. Eredményeink szerint az üres és teljes életet élók csoportja mindegyik vizsgált változó mentén különbözik (flow-élmény gyakorisága egyéni és társas helyzetben, flowélmény minósége, flow-szinkronizációs összetevók), a hatásmérték közepes értékeket vesz fel, a megmagyarázott varianciaarány 5-13\% között mozog.

Az élvezetes és jelentésteli boldogságorientációt követô csoportok nem különböztek észlelhetôen a flow és flow-szinkronizációs összetevók mentén.

Következtetések: Eredményeink alapján valószinüsithetô, hogy a flow-élmény társas helyzetben mind az élvezetes (hedonisztikus) boldogságúthoz (az élményt követô pozitív érzelmek megtapasztalása segítségével), mind pedig az értelemteli (eudaimonikus) boldogságúthoz hozzáköthetô (a fejlôdés és növekedés, motivált cselekvés végzése útján), továbbá feltehetôleg a teljes élethez szükséges.

Kulcsszavak: flow, flow-szinkronizáció, társas interakció, teljes élet, üres élet, boldogságorientációk 


\section{BEVEZETÉS}

Az áramlatélmény (Csíkszentmihályi, 1975) azt a szubjektív állapotot jelöli, melyet a személy egy kihívást jelentô tevékenységbe való teljes bevonódáskor tapasztal. A flow (áramlat) a jóllét növelésének egyik eszköze is lehet (Csíkszentmihályi, 1999; Lyubomirsky, 2008). A jóllét fogalma képviseli azt, amit az emberek a boldogságról gondolnak (Martin-Krumm és mtsai, 2014), több, mint a pozitív érzelmek gyakori jelenléte (Diener, 1984). A társas támogatás, a pozitív kapcsolatok mind hozzájárulnak a mentális egészséghez (Park és mtsai, 2014), mely a jóllét tüneteinek szindrómájának tekinthetô (Keyes, 2002), azonban kérdés, hogy a társas hatás az áramlatélményen keresztül hogyan járul hozzá a jólléthez.

Az arisztotelészi eudaimonikus (értelemkeresô, jelentéstaláló, növekedésalapú), továbbá a hedonikus (örömmaximalizáló) boldogságút mellett (Kashdan, Biswas-Diener és King, 2008) Peterson, Park és Seligman (2005) harmadikként az elkötelezett élet útját azonosították, mely a flow-élményben gazdag életet jelöli (Csíkszentmihályi, 1990), és összefüggésben van mind az élvezetes, mind pedig a jelentésteli boldogságúttal (Waterman, Schwartz és Conti, 2008).

Mivel az elkötelezett élethez szükséges flow-élmény átélése kevésbé gyakori, ezért kevésbé tekinthetô tipikus boldogságútnak (Anić és Tončić, 2013). Ezenkívül probléma lehet, hogy az elkötelezett élet korrelál mind az élvezetes, mind a jelentésteli élettel, tehát nem tekinthetjük jól elkülöníthetô, önálló faktornak a boldogságutak megjelölésekor (Waterman és mtsai, 2008, Anić és Tončić, 2013).

A mindennapos jóllét megtapasztalásához, tehát a teljes élethez mindhárom boldogságútra szükség van (Peterson és mtsai, 2005), ezzel ellentétben pedig az üres életet élô személy mindhárom boldogságorientációt alacsony szinten éli meg. A boldogságutak preferenciájának mérése a Boldogságorientáció Kérdôívvel történik, a szerzók javaslata alapján a mindhárom skálára adott magas és alacsony pontszámokkal különíthetôk el a teljes és üres életet élő személyek (Peterson és mtsai, 2005). Egy kutatásban a kérdôív kétfaktoros megoldásával (hedonisztikus, eudaimonikus boldogságutak) dolgoztak, így a teljes és üres életet éló személyek csoportját a két faktoron elért pontszámok alapján határozták meg (Anić és Tončić, 2013). Mivel egy igazoltan érvényes mérôeszközrôl van szó (Anić és Tončić, 2013; Chen, 2010; Martin-Krumm és mtsai, 2014; Szondy és Martos, 2014), valószínúsíthetô, hogy ezek a pontszámok a személyek valódi szubjektív megítélését tükrözik.

Az áramlat mint optimális élmény affektív (rövid távon: pozitív irányú hangulatváltozás; hosszú távon: hatás a különbözố jóllétkomponensekre) és kognitív (kapacitás növekedése, feldolgozási stílusok fejlốdése) következményekkel is járhat (Keller és Landhäußer, 2012), az élmény hatásaira azonban mégis kevesebb vizsgálat fókuszál (Engeser és Schiepe-Tiska, 2012). Feltételezhetô, hogy a flow-élmény átélése és a jóllét különbözô dimenziói tekintetében körkörös okságról beszélhetünk, mivel a flow-élmény nem csak előrejelzô tényezôje lehet pl. a szubjektív jóllétnek (Fritz és Avsec, 2007), hanem az eredmények szerint a magasabb boldogságszinttel rendelkezó személyek intenzívebb flow-élményt is tapasztalnak (Sahoo és Sahu, 2009).

Több koncepció született az optimális élmény társas helyzetben való megtapasztalásának következményeirôl: az élmény kapcsolatban van pozitív érzelmekkel, pl. az 
öröm érzésével (Gaggioli, Milani, Mazzoni és Riva, 2011; Salanova, Rodríguez-Sánchez, Schaufeli és Cifre, 2014; Walker, 2010); élvezetesebb, mint egyénileg (Walker, 2010), az élvezethez járul hozzá (Sweetser, Johnson és Wyeth, 2012; Sweetser és Wyeth, 2005), magasabb teljesítményt eredményez (Gaggioli és mtsai, 2011; Sawyer, 2008), és minôségileg is más jelenség a társas kontextus hatása miatt (Walker, 2010), magasabb szintû, intenzívebb élményt biztosít, mint egyedül (Magyaródi és Oláh, 2017).

A kihívást jelentô tevékenységben a partnerek közötti koordinációs tendencia elvezethet akár a mentális állapotok konvergenciájához is (Bakker, 2005), a flow-szinkronizációhoz (Magyaródi és Oláh, 2015b, 2016), mely a közös, kihívást jelentô tevékenységek közben létrejövô szubjektív flow-élmény és az interakció sajátosságainak egymásra hatását írja le, kiemelve az élménytöbblet jelentôségét (Magyaródi és Oláh, 2017).

A boldogságorientáció és a flow kapcsolatában a társas aspektus inkább következményként merült fel eddig: egyetemi hallgatóknál az elkötelezett élet mint boldogságorientáció növeli a közösségbe való bevonódást (Gabriele, 2008). Bár a flow-élmény társas szituációkban való átélésének jólléttel való kapcsolata egyelôre nem tisztázott, számos elképzelés kiemeli a szociabilitás (Harker és Keltner, 2001) és társas támogatás (Lakey, 2013) jóllétre ható pozitív szerepét. Az élvezetes, új és izgalmas, megosztott tevékenységekben való részvétel fokozza a pszichológiai jóllétet (Snyder és Lopez, 2010), így feltételezésünk szerint a társas helyzetben tapasztalt flow-élmény, valamint az élményt támogató flow-szinkronizációs összetevơk kapcsolódnak a jóllét különbözó koncepcióihoz, gyakoriságuk és intenzitásuk hozzájárulhat a teljes élethez (Anić és Tončić, 2013). Kutatásunkban a társas helyzetben tapasztalt flow-élmény boldogságorientációkhoz való kapcsolódását kívánjuk tisztázni.

\section{HIPOTÉZISEK}

Hipotéziseink a következók:

1. Feltételezzük, hogy a boldogságorientációs koncepció kritikái alapján, mely a három boldogságút létezését kérdôjelezi meg (Anić és Tončić, 2013), kizárólag a hedonisztikus (élvezetes élet) és eudaimonikus (jelentésteli élet) boldogságutak mentén elkülöníthetô egy teljes életet élő, valamint egy üres életet élő csoport a hedonisztikus és eudaimonikus csoportok mellett. A boldogságorientáció-pontszámok alapján (Peterson és mtsai, 2005), tehát azt várjuk, hogy elemzésünkben a következó csoportokat kapjuk:

a) Élvezetes életet élô csoport: magas pontszámot kap az Élvezetes élet skálán, alacsony pontszámot a Jelentésteli élet skálán.

b) Jelentésteli életet éló csoport: alacsony pontszámot kap az Élvezetes élet skálán, magas pontszámot a Jelentésteli élet skálán.

c) Teljes életet élô csoport: magas pontszámot kap az Élvezetes élet skálán, magas pontszámot a Jelentésteli élet skálán.

d) Üres életet élô csoport: alacsony pontszámot kap az Élvezetes élet skálán, alacsony pontszámot a Jelentésteli élet skálán. 
2. Amennyiben az 1. hipotézisben feltételezett csoportalkotás lehetséges, tehát elkülöníthetô az üres és teljes életet élô csoport a mintában, úgy feltételezzük, hogy

a) a teljes életet élố személyek mind a flow-gyakoriság és -élménykomponensek, mind a flow-szinkronizációs komponensek vonatkozásában különböznek;

b) a hedonisztikus és eudaimonikus csoportok között nem lesz különbség, mivel a flow-élmény mindkét boldogságúthoz kapcsolódik (Waterman és mtsai, 2008).

\section{MÓDSZER}

\section{Minta}

1060 felnôtt vizsgálati személy vett részt a kutatásban, átlagéletkoruk 26,67 év (szórás $=10,76$ ), a minta 34,6\%-a nó, 65,4\%-a férfi. A résztvevók 41\%-a budapesti, $20,8 \%$ vidéki nagyvárosban, 25,2\%-a vidéki kisvárosban, faluban, 13\%-uk pedig külföldön él. A válaszadók 44,4\%-a egyedülálló, 55,6\% él kapcsolatban. Alapfokú végzettséggel a minta 3,5\%-a, középfokúval a 63,6\%-a, felsófokúval a 32,9\%-a rendelkezik. A részvétel önkéntes alapú, anonim, mintavételi eljárásként kényelmi és hólabda módszerekkel dolgoztunk.

\section{Eszközök}

A vizsgálati személyek online kérdôíves felületen vettek részt a kutatásban. A demográfiai kérdések (nem, életkor, lakóhely, kapcsolati állapot, iskolai végzettség) megválaszolása után a résztvevôk a flow-élményhez és a jóllétkoncepciókhoz kapcsolódó mérôeszközöket töltöttek ki.

- Általános Flow Leírás (ÁFL) (Magyaródi és Oláh, 2015a). Az Általános Flow Index (General Flow Index) (Jackson és Roberts, 1992) alapján alkottunk egy leírást az áramlatélményrôl, melyet elolvasva a válaszadó értékeli egy-egy ötfokú Likertskálán (1: Egyáltalán nem - 5: Egészen nagy mértékben), hogy milyen gyakran, milyen intenzíven tapasztalja ezt az élményt (jelen kutatásban kizárólag a gyakoriságskálát használtuk). A leírás segítségével azonosítható az a legjellemzóbb tevékenység is, amely során az élményt tapasztalja a személy.

- Általános Flow Leírás Társas Interakciókban (ÁSZFL) (Magyaródi és Oláh, 2015a): A válaszadó egy leírást olvashat a társas helyzetben átélhetô flow-élményrôl, mely után értékeli egy-egy ötfokú Likert-skálán (1: Egyáltalán nem - 5: Egészen nagy mértékben), hogy milyen gyakran, milyen intenzíven tapasztalja (jelen vizsgálatban kizárólag a gyakorisági változót elemeztük). A leírást alkalmaztuk a vizsgálatban annak a közös, társas tevékenységnek az azonosítására, melyben a vizsgálati személy leggyakrabban átéli a flow-élményt.

- Flow Állapot Kérdôiv (Magyaródi, Nagy, Soltész, Mózes és Oláh, 2013): A Flow Állapot Kérdôív (FÁK) az áramlatélmény alapdimenzióit méri, 20 itemen keresztül. 
A résztvevôk ötfokú Likert-skálán értékelik az egyes állításokat (1: Egyáltalán nem értek egyet - 5: Teljesen egyetértek). A FÁK két alskálából áll: (1) a Kihívás-készség egyensúly skálából, mely a flow-zónába lépés alapvetô feltételeire utal, az (2) Egybeolvadás az élménnyel skála pedig a flow kísérôjelenségeit foglalja össze. A skálák reliabilitása elfogadható $\left(\alpha_{\mathrm{K}-\mathrm{K}}=0,92 ; \alpha_{\mathrm{E}}=0,91\right)$. A válaszadó a jelölt tevékenység során általában tapasztalt élményeirôl számol be. A kérdôív jelen vizsgálatban a partnerrel közös tevékenység során tapasztalható áramlatélményre vonatkozik.

- Flow Szinkronizáció Kérdôiv (Magyaródi és Oláh, 2015b): A Flow Szinkronizáció Kérdôív (FSZK) 28 tételes kérdốív 5 skálán keresztül ragadja meg azokat a tényezóket, melyek a közös interakciós flow-helyzetben az átélt élményt kísérik, támogatják. A skálák a következók: (1) Hatékonyság és összehangoltság a partnerrel; (2) Bevonódásélmény és koncentráció; (3) Motiváció és pozitív hatás a partnerre; (4) Motiváció és tanulás a személy számára; (5) Koordináció a partnerrel a tevékenység közben. A résztvevôk ötfokú Likert-skálán (1: Egyáltalán nem - 5: Teljes mértékben) válaszolnak. A skálák reliabilitása megfelelô $(0,80 \leq \alpha \leq 0,93)$. A válaszadó a jelölt tevékenység során általában tapasztalt élményeirôl számol be. A kérdôív jelen vizsgálatban a partnerrel közös tevékenység során tapasztalható flow-szinkronizációs összetevókre vonatkozik.

- Boldogságorientáció skála (Orientations to Happiness, OTH) (Peterson és mtsai, 2005): A kérdôív 18 tétel segítségével méri a boldogságkeresés három útját (élvezetes, elkötelezett és jelentésteli élet). A tételeket a résztvevő ötfokú Likert-skálán értékeli (1: Egyáltalán nem illik rám - 5: Teljesen illik rám). A mérôeszköz eredeti (élvezetes: $\alpha=0,82$, elkötelezett: $\alpha=0,72$, jelentésteli: $\alpha=0,82$ ) (Peterson és mtsai, 2005) és magyar nyelvre adaptált verziójának skálái elfogadható reliabilitásmutatókkal bírnak (élvezetes: $\alpha=0,82$, elkötelezett: $\alpha=0,64$,jelentésteli: $\alpha=0,78$ ) (Szondy és Martos, 2014).

\section{Eljárás}

A résztvevôk toborzása egyetemi kurzusokon és közösségimédia-felületeken történt, a részvétel feltételei a következók voltak: 18. életév betöltése, pszichiátriai és neurológiai problémáktól való mentesség. A kérdőív kitöltése online felületen történt, a tájékoztató elolvasása és a vizsgálatba történô beleegyezés után 15-20 percet vett igénybe.

\section{Statisztikai elemzés}

A változók leíró statisztikai elemzésében azok átlagát, szórását, reliabilitását (Cronbachalpha), valamint normalitását teszteljük (Shapiro-Wilk-módszerrel). Ezután ismertetjük a változók közötti kapcsolatot Spearman-féle rangkorrelációs elemzéssel. A hipotézisek teszteléséhez K-központú klaszterelemzést alkalmazunk, relokációval (Vargha és Borbély, 2016). 


\section{Etikai vonatkozások}

Az Eötvös Loránd Tudományegyetem Kutatásetikai Bizottsága támogatta a vizsgálat megvalósítását (Iktatási szám: 2014/13).

\section{EREDMÉNYEK}

A vizsgálat során alkalmazott változók leíró statisztikai eredményeit, belsô konzisztenciamutatóit, valamint a változók normalitásvizsgálatának eredményét (Ghasemi és Zahediasl, 2012) az 1. táblázatban ismertetjük, a korrelációs elemzések a Függelékben (5. táblázat) olvashatók.

1. táblázat. Az elemzés során alkalmazott változók leíró statisztikája, reliabilitás- és normalitásmutatói

\begin{tabular}{lcccc}
\hline Skála & Átlag & szórás & $\alpha$ & W\# \\
\hline ÁFL: flow-élmény gyakorisága & 3,49 & 0,86 & - & $0,88^{* *}$ \\
ÁSZFL: flow-élmény gyakorisága & 3,22 & 0,94 & - & $0,90^{* *}$ \\
FÁK: 1. Kihívás-készség egyensúly & 3,76 & 0,49 & 0,84 & $0,97^{* *}$ \\
FÁK: 2. Egybeolvadás az élménnyel & 3,46 & 0,47 & 0,81 & $0,98^{* *}$ \\
FÁK: Összpontszám & 3,62 & 0,40 & 0,85 & $0,96^{* *}$ \\
FSZK: 1. Hatékonyság és összehangoltság a partnerrel & 4,29 & 0,58 & 0,93 & $0,92^{* *}$ \\
FSZK: 2. Bevonódásélmény és koncentráció & 3,83 & 0,81 & 0,82 & $0,96^{* *}$ \\
FSZK: 3. Motiváció és pozitív hatás a partnerre & 4,06 & 0,70 & 0,83 & $0,93^{* *}$ \\
FSZK: 4. Motiváció és tanulás a személy számára & 4,10 & 0,70 & 0,79 & $0,94^{* *}$ \\
FSZK: 5. Koordináció a partnerrel a tevékenység közben & 3,46 & 0,82 & 0,80 & $0,98^{* *}$ \\
FSZK: Összpontszám & 3,95 & 0,58 & 0,94 & $0,98^{* *}$ \\
OTH: Élvezetes élet & 3,34 & 0,71 & 0,76 & $0,99 * *$ \\
OTH: Elkötelezett élet & 3,22 & 0,59 & 0,64 & $0,99 * *$ \\
OTH: Jelentésteli élet & 3,36 & 0,79 & 0,80 & $0,99 * *$ \\
\hline
\end{tabular}

Megjegyzés: $\alpha=$ Cronbach- $\alpha$ mutató. $W=$ Shapiro-Wilk-teszt. \#: szabadságfok $=1060$. $* *=p<0,01$.

$\mathrm{Az}$ 1. hipotézis teszteléséhez K-központú klaszterelemzéssel az élvezetes és jelentésteli boldogságorientációt leíró változókkal a résztvevôkből csoportokat alkottunk. A klaszterek meghatározását a Ward-típusú hierarchikus elemzéssel kezdtük, majd az adekvációs mutatók alapján választottuk ki, hogy erre a négy klaszterre alkalmazunk relokációt (Vargha, Torma és Bergman, 2015). A relokáció utáni megmagyarázott hibaszázalék megfelelô (EESS\% = 67,28). Az eredeti elméleti feltételezés alapján (Fritz és Avsec, 2007) ez a két boldogságút önállóan is alkalmazható, valamint mindkettô párhuzamos alkalmazása teljes élethez, ezek hiánya üres élethez vezethet. A standardizált átlagok mintázata alapján (2. táblázat) megállapítható, hogy elkülöníthetô egy teljes és egy üres életet élő, valamint egy jelentésteli és egy élvezetes boldogságorientációt követô csoport, kiegyenlített mintaelemszámmal. 
2. táblázat. Az élvezetes és jelentésteli boldogságorientáció alapján képzett klaszterek

\begin{tabular}{lcccc}
\hline Klaszter & $N$ & $H C$ & $\begin{array}{c}\text { Élvezetes élet } \\
\text { Átlag (szórás) }\end{array}$ & $\begin{array}{c}\text { Jelentésteli élet } \\
\text { Átlag (szórás) }\end{array}$ \\
(1) Üres élet & 265 & 0,71 & $2,65(0,44)$ & $2,63(0,46)$ \\
(2) Élvezetes élet & 247 & 0,64 & $3,77(0,37)$ & $2,74(0,48)$ \\
(3) Teljes élet & 296 & 0,62 & $4,00(0,42)$ & $4,02(0,42)$ \\
(4) Jelentésteli élet & 252 & 0,66 & $2,85(0,41)$ & $3,95(0,46)$ \\
\hline
\end{tabular}

Megjegyzés: $H C=$ homogenitási együttható.

A 2. hipotézis teszteléséhez megvizsgáljuk az üres és teljes életet élook közötti eltéréseket, valamint az örömteli és jelentésteli boldogságorientációt követô csoportok közötti eltéréseket, a flow-gyakoriság, flow-intenzitás és flow-szinkronizációs faktorok tekintetében. Ugyan nagy mintás vizsgálatot végeztünk, de a változók nem követik a normális eloszlást, így a trimmelt átlagok összehasonlítását Yuen-próbával végezzük (maximum trimmelés: 10\%) (3. táblázat és 4. táblázat).

3. táblázat. Az üres és teljes életet élố csoportok páronkénti összehasonlítása a flow-gyakoriság, flow-intenzitás és flow-szinkronizációs összetevôk mentén

\begin{tabular}{|c|c|c|c|c|c|c|}
\hline & \multirow{2}{*}{$\begin{array}{l}\text { Üres élet } \\
\text { trimmelt } M \\
\text { (Winsor, } s \text { ) }\end{array}$} & \multirow{2}{*}{$\begin{array}{l}\text { Teljes élet } \\
\text { trimmelt } M \\
\text { (Winsor, } s \text { ) }\end{array}$} & \multirow[b]{2}{*}{$Y(f)$} & \multirow[b]{2}{*}{$p$} & \multicolumn{2}{|c|}{ Hatás-mérték } \\
\hline & & & & & $d$ & $e t a^{2}$ \\
\hline ÁFL: flow-gyakoriság & $3,33(0,69)$ & $3,71(0,72)$ & $-5,09(447,2)$ & $<0,01$ & $-0,44$ & 0,05 \\
\hline ÁFSZL: gyakoriság & $2,95(0,74)$ & $3,42(0,89)$ & $-5,48(446,7)$ & $<0,01$ & $-0,49$ & 0,06 \\
\hline $\begin{array}{l}\text { FÁK: 01. Kihívás-készség } \\
\text { egyensúly }\end{array}$ & $3,62(0,37)$ & $3,85(0,36)$ & $-5,97(439,6)$ & $<0,01$ & $-0,49$ & 0,06 \\
\hline $\begin{array}{l}\text { FÁK: } 02 \text {. Egybeolvadás az } \\
\text { élménnyel }\end{array}$ & $3,29(0,33)$ & $3,56(0,38)$ & $-7,42(448,6)$ & $<0,01$ & $-0,58$ & 0,08 \\
\hline FÁK: Összpontszám & $3,47(0,28)$ & $3,72(0,28)$ & $-8,66(442,6)$ & $<0,01$ & $-0,65$ & 0,10 \\
\hline $\begin{array}{l}\text { FSZK: } 01 \text {. Hatékonyság } \\
\text { és összehangoltság a } \\
\text { partnerrel }\end{array}$ & $4,15(0,54)$ & $4,48(0,45)$ & $-6,38(417,3)$ & $<0,01$ & $-0,55$ & 0,07 \\
\hline $\begin{array}{l}\text { FSZK: } 02 . \\
\text { Bevonódásélmény és } \\
\text { koncentráció }\end{array}$ & $3,56(0,67)$ & $4,19(0,56)$ & $-9,60(414,5)$ & $<0,01$ & $-0,77$ & 0,13 \\
\hline $\begin{array}{l}\text { FSZK: 03. Motiváció és } \\
\text { pozitív hatás a partnerre }\end{array}$ & $3,83(0,57)$ & $4,30(0,56)$ & $-7,94(440,2)$ & $<0,01$ & $-0,60$ & 0,08 \\
\hline $\begin{array}{l}\text { FSZK: } 04 \text {. Motiváció és } \\
\text { tanulás a személy számára }\end{array}$ & $3,90(0,60)$ & $4,31(0,52)$ & $-6,96(427,0)$ & $<0,01$ & $-0,53$ & 0,07 \\
\hline $\begin{array}{l}\text { FSZK: } 05 \text {. Koordináció a } \\
\text { partnerrel a tevékenység } \\
\text { közben }\end{array}$ & $3,22(0,64)$ & $3,72(0,71)$ & $7,10(449,0)$ & $<0,01$ & $-0,59$ & 0,08 \\
\hline FSZK: Összpontszám & $3,72(0,48)$ & $4,17(0,46)$ & $-9,02(438,9)$ & $<0,01$ & $-0,77$ & 0,13 \\
\hline
\end{tabular}

Megjegyzés: Winsor: $s$ = Winsorizált szórás, $M=$ átlag, $Y(f)=$ Yuen-próba eredménye szabadságfokkal, $p=$ szignifikanciaérték, $d=$ Cohen-delta, $e t a^{2}=$ megmagyarázott varianciaarány. 
Az eredmények szerint az üres és teljes életet élók csoportja mindegyik vizsgált változó mentén különbözik, a hatásmérték közepes értékeket vesz fel, a megmagyarázott varianciaarány 5-13\% között mozog, a csoporttagság alapján történố becslés pontosságáról informál.

4. táblázat. Az élvezetes és jelentésteli boldogságorientációt követố csoportok páronkénti összehasonlítása a flow-gyakoriság, flow-intenzitás és flow-szinkronizációs komponensek mentén

\begin{tabular}{lcccc}
\hline & $\begin{array}{c}\text { Élvezetes élet } \\
\text { trimmelt átlag } \\
\text { (Winsor. } s)\end{array}$ & $\begin{array}{c}\text { Jelentésteli élet } \\
\text { trimmelt átlag } \\
\text { (Winsor. } s)\end{array}$ & Y(f) & $\mathrm{p}$ \\
\hline ÁFL: flow-gyakoriság & $3,43(0,50)$ & $3,52(0,69)$ & $1,21(367,4)$ & 0,19 \\
ÁFSZL: gyakoriság & $3,28(0,74)$ & $3,24(0,74)$ & $0,50(398,7)$ & 0,62 \\
FÁK: 01. Kihívás-készség egyensúly & $3,78(0,34)$ & $3,82(0,34)$ & $-0,96(396,5)$ & 0,34 \\
FÁK: 02. Egybeolvadás az élménnyel & $3,47(0,36)$ & $3,52(0,34)$ & $-1,15(397,6)$ & 0,25 \\
FÁK: Összpontszám & $3,65(0,30)$ & $3,68(0,30)$ & $-1,12(398,3)$ & 0,26 \\
FSZK: 01. Hatékonyság és összehan- & $4,34(0,43)$ & $4,40(0,46)$ & $-1,10(397,8)$ & 0,27 \\
goltság a partnerrel & & & & \\
FSZK: 02. Bevonódás élmény és kon- & $3,85(0,73)$ & $3,88(0,68)$ & $-0,37(394,9)$ & 0,71 \\
centráció & & & & \\
FSZK: 03. Motiváció és pozitív hatás & $4,03(0,62)$ & $4,25(0,58)$ & $-3,32(395,3)$ & $<0,01$ \\
a partnerre & & & & \\
FSZK: 04. Motiváció és tanulás a sze- & $4,15(0,55)$ & $4,26(0,59)$ & $-1,75(398,2)$ & 0,08 \\
mély számára & & & & \\
FSZK: 05. Koordináció a partnerrel a & $3,48(0,70)$ & $3,49(0,68)$ & $0,03(398,9)$ & 0,98 \\
tevékenység közben & $3,94(0,45)$ & $4,02(0,47)$ & $-1,59(398,8)$ & 0,11 \\
\hline FSZK: Összpontszám & & &
\end{tabular}

Megjegyzés: Winsor. $s=$ Winsorizált szórás, $M=$ átlag, $Y(f)=$ Yuen-próba eredménye szabadságfokkal, $p=$ szignifikanciaérték.

Az elemzések alapján a jelentésteli élet boldogságorientációjával rendelkezô személyek magasabb szintû pozitív, motiváló hatást tapasztalnak, mint az élvezetes életet élô személyek, a hatás mértéke alacsony $\left(d=0,28\right.$, et $\left.a^{2}=0,02\right)$. Az eredmények szerint alapvetôen nincs érzékelhetô különbség az örömteli és jelentésteli boldogságorientációt követô csoportok között, a társas helyzetben tapasztalt flow-élmény gyakorisága és jellemzői vonatkozásában.

\section{DISZKUSSZIÓ}

Kérdôíves vizsgálatunk célja az áramlatélmény és jóllétkutatások eredményeinek kibôvítése volt, a flow társas helyzetben való megjelenése és a boldogságorientációk közötti kapcsolat vizsgálatával.

Kutatásunkban reprodukáltuk az üres és teljes életre vonatkozó eredményeket (Anić és Tončić, 2013), továbbá az élvezetes élet (örömmaximalizáló) és jelentésteli élet (értelemtaláló) stratégiákat követô csoportokat is azonosítani tudtuk a vizsgálati 
mintán, az arisztotelészi hagyományoknak megfelelốen (Aristotle, 1999). Az élvezetes élet megközelítés leginkább a szubjektív jólléthez kapcsolható (Diener, 1994), míg az értelemtaláló megközelítés inkább személyes növekedést és önmegvalósítást foglal magában (Waterman és mtsai, 2008). Valamivel magasabb hatásmértékú különbség található a társas helyzetben átélt flow gyakoriságát illetôen az üres és teljes életet élôk között, mint az egyedüli helyzetben átélt áramlat esetében: fontos kérdés a további kutatásokban, hogy a társas dimenzió miatt a jóllétre vonatkozóan is többlethatás (Magyaródi és Oláh, 2017) figyelhetô-e meg.

Az eredmények szerint a flow-élmény gyakorisága és társas helyzetben átélt szubjektív dimenziói vonatkozásában nincs számottevô különbség az örömteli és jelentésteli életet élố csoportok között, az üres és teljes életet élók között azonban mindegyik dimenzió tekintetében különbséget találunk: a teljes életet élókre jellemzóbb a flowélmény átélése a társas interakció során. Feltételezzük tehát, hogy mindkét boldogságorientációhoz köthetô az áramlatélmény, a rövid távú pozitív következmények miatt a hedonisztikus stratégiához (Csíkszentmihályi és Wong, 1991), az önmegvalósítás és fejlôdés miatt pedig az eudaimonikus életúthoz (Kashdan és mtsai, 2008).

A vizsgálatban ugyan nagy elemszámú mintával dolgoztunk, azonban a résztvevôk kényelmi, hólabda mintavétellel lettek bevonva a vizsgálatba. A visszatekintési torzítás (Hassan, 2005), valamint a mintavétel módja miatt az általánosíthatóság hiánya is a kutatás limitációi közé tartozik. Keresztmetszeti vizsgálattal dolgoztunk, de feltételezéseink megalapozásához, az ok-okozati vagy cirkuláris összefüggések (Fredrickson, 1998) igazolásához szükség lehet a jövooben egy longitudinális elrendezéssel végzett kutatásra. A hosszmetszeti kutatással a hétköznapi aktuális élmények és a jóllét dimenzióinak többszöri értékelésével a gyüjtött adatok pontossága nôhet. Amennyiben a flow-élmény átélésének vizsgálatát a diádikus szinten túlra, akár csoportokra ki tudjuk terjeszteni, úgy több személy bevonásával, a személy csoporthoz, társadalomhoz tartozásával a szociális jóllét dimenziói is vizsgálhatóvá válnak (Keyes, 1998).

A korábbi társas élményekre való visszaemlékezés magasabb szintû pozitív érzelmeket eredményez, és mivel akár az alkalomszerú, adott tevékenységhez kötött társas kapcsolatok is pozitív hatással bírnak a jóllétre (Sandstrom és Dunn, 2014), így azon intervenciók bevezetése, melyek különbözô társas kontextusokban (pl. iskola, munkahely) a flow-élmény feltételeinek megteremtését célozzák meg, és hozzájárulnának a résztvevôk jóllétének növeléséhez is. 


\section{KÖSZÖNETNYILVÁNÍTÁS}

Köszönöm Prof. Dr. Oláh Attila témavezetôi munkáját a doktori munkám során, továbbá Prof. Dr. Vargha Andrásnak a segítségét a doktori kutatásaim statisztikai elemzéseihez kapcsolódóan.

\section{IRODALOM}

Anić, P., \& Tončić, M. (2013). Orientations to Happiness, Subjective Well-being and Life Goals. Psihologijske Teme, 22(1), 135-153.

Aristotle (1999). Nicomachean Ethics. 2nd edition. Indianapolis: Hackett Publishing Company, Inc.

Bakker, A. B. (2005). Flow among music teachers and their students: The crossover of peak experiences. Journal of Vocational Behavior, 66(1), 26-44. https://doi.org/10.1016/j. jvb.2003.11.001

Chen, G.-H. (2010). Validating the Orientations to Happiness Scale in a Chinese Sample of University Students. Social Indicators Research, 99(3), 431-442. https://doi.org/10.2307/40927604

Csíkszentmihályi, M. (1975). Beyond Boredom and Anxiety. San Francisco: Jossey-Bass Publishers.

Csíkszentmihályi, M. (1990). Flow: The Psychology of Optimal Experience. New York: Harper \& Row.

Csíkszentmihályi, M. (1999). If We Are So Rich, Why Aren’t We Happy? American Psychologist, 54(10), 821-827.

Csíkszentmihályi, M., \& Wong, M. M.-H. (1991). The Situational and Personal Correlates of Happiness: A Cross-National Comparison. In F. Strack, M. Argyle, \& N. Schwartz (Eds), The Social Psychology of Subjective Well-Being (pp. 69-88). London: Pergamon Press. https://doi. org/10.1007/978-94-017-9088-8

Diener, E. (1984). Subjective Well-being. Pyschological Bulletin, 95(3), 542-575.

Diener, E. (1994). Assessing subjective well-being: Progress and opportunities. Social Indicators Research, 31(2), 103-157. https://doi.org/10.1007/BF01207052

Engeser, S., \& Schiepe-Tiska, A. (2012). Historical Lines and Overview of Current Research on Flow. In S. Engeser (Ed), Advances in Flow Research (pp. 1-22). New York: Oxford University Press. https:/ /doi.org/10.1007/978-1-4614-2359-1_1

Fredrickson, B. L. (1998). What Good Are Positive Emotions? Review of General Psychology, 2(3), 300-319. https://doi.org/10.1037/1089-2680.2.3.300

Fritz, B. S., \& Avsec, A. (2007). The Experience of Flow and Subjective Well-being of Music Students. Horizons of Psychology, 16(2), 5-17. https://doi.org/10.1177/0022429411434931

Gabriele, R. (2008). Orientations to Happiness: Do They Make a Difference in a Student's Educational Life? American Secondary Education, 36(2), 88-101. https://doi.org/10.2307/41406111

Gaggioli, A., Milani, L., Mazzoni, E., \& Riva, G. (2011). Networked Flow: A Framework for Understanding the Dynamics of Creative Collaboration in Educational and Training Settings. The Open Education Journal, 4(1), 41-49. https://doi.org/10.2174/1874920801104010041

Ghasemi, A., \& Zahediasl, S. (2012). Normality tests for statistical analysis: a guide for nonstatisticians. International Journal of Endocrinology and Metabolism, 10(2), 486-489. https:/ / doi. org/10.5812/ijem.3505

Harker, L., \& Keltner, D. (2001). Expressions of Positive Emotion in Women's College Yearbook Pictures and Their Relationship to Personality and Life Outcomes Across 
Adulthood. Journal of Personality and Social Psychology, 80(1), 112-124. https://doi. org/10.1037//0022-3514.80.1.112

Hassan, E. S. (2005). Recall Bias can be a Threat to Retrospective and. The Internet Journal of Epidemiology, 3(2), 1-7.

Jackson, S. A., \& Roberts, G. C. (1992). Positive Performance States of Athletes: Toward a Conceptual Understanding of Peak Performance. The Sport Psychologist, 6, 156-171.

Kashdan, T. B., Biswas-Diener, R., \& King, L. A. (2008). Reconsidering happiness: the costs of distinguishing between hedonics and eudaimonia. The Journal of Positive Psychology, 3(4), 219-233. https://doi.org/10.1080/17439760802303044

Keller, J., \& Landhäußer, A. (2012). The Flow Model Revisited. In S. Engeser (Ed), Advances in Flow Research (pp. 51-64). New York: Springer.

Keyes, C. L. M. (1998). Social wellbeing. Social Psychology Quarterly. https://doi. org $/ 10.2307 / 2787065$

Keyes, C. L. M. (2002). The Mental Health Continuum: From Languishing to Flourishing in Life. Journal of Health and Social Research, 43(2), 207-222. https://doi.org/10.2307/3090197

Lakey, B. (2013). Perceived Social Support and Happiness: The Role of Personality and Relational Processes. In I. Boniwell, S. A. David, \& A. Conley Ayers (Eds), Oxford Handbook of Happiness (pp. 847-859). Oxford: Oxford University Press. https://doi.org/10.1093/oxfordhb/9780199557257.013.0062

Lyubomirsky, S. (2008). Hogyan legyünk boldogok? Életünk átalakításának útjai tudományos megközelitésben. Budapest: Ursus Libris Kiadó.

Magyaródi, T., Nagy, H., Soltész, P., Mózes, T., \& Oláh, A. (2013). Egy újonnan kidolgozott Flow Állapot Kérdôív kimunkálásának és pszichometriai jellemzóinek bemutatása. Pszichológia, 33(1), 15-36. https://doi.org/10.1556/Pszicho.33.2013.1.2

Magyaródi, T., \& Oláh, A. (2015a). A Cross-Sectional Survey Study About the Most Common Solitary and Social Flow Activities to Extend the Concept of Optimal Experience. Europe's Journal of Psychology, 11(4), 632-650. https://doi.org/10.5964/ejop.v1li4.866

Magyaródi, T., \& Oláh, A. (2015b). Flow Szinkronizáció Kérdôív: az optimális élmény mechanizmusának mérése társas interakciós helyzetekben. Mentálhigiéné és Pszichoszomatika, 16(3), 271-296. https://doi.org/10.1556/0406.16.2015.3.4

Magyaródi, T., \& Oláh, A. (2016). A Flow Szinkronizáció Kérdôív pszichometriai jellemzôii: reliabilitás- és validitásvizsgálat. Mentálhigiéné és Pszichoszomatika, 17(2), 145-166. https://doi. org/http://dx.doi.org/10.1556/0406.17.2016.2.4

Magyaródi, T., \& Oláh, A. (2017). The Effect of Social Interaction on Flow Experience. International Journal of Psychology \& Behavior Analysis Open Access, 3(126), 1-5. https://doi. org/10.15344/2455-3867/2017/126

Martin-Krumm, C., Kern, L., Fontayne, P., Romo, L., Halim Boudoukha, A., Boniwell, I., et al. (2014). French adaptation of the Orientation to Happiness Scale and the impact of Quality of Life in French Students. Social Indicators Research, 124(1), 259-281. https://doi.org/ https://psycnet.apa.org/doi/10.1007/s11205-014-0774-8

Park, N., Peterson, C., Szvarca, D., Vander Molen, R. J., Kim, E. S., \& Collon, K. (2014). Positive Psychology and Physical Health: Research and Applications. Americal Journal of Lifestyle Medicine, 1-7. https://doi.org/10.1177/1559827614550277

Peterson, C., Park, N., \& Seligman, M. E. P. (2005). Orientations to Happiness and Life satisfaction: The Full Life Versus the Empty Life. Journal of Happiness Studies, 6(1), 25-41. https:// doi.org/10.1007/s10902-004-1278-z

Sahoo, F. M., \& Sahu, R. (2009). The Role of Flow Experience in Human Happiness. Journal of the Indian Academy of Applied Psychology, 35(spec iss), 40-47. 
Salanova, M., Rodríguez-Sánchez, A. M., Schaufeli, W. B., \& Cifre, E. (2014). Flowing Together: A Longitudinal Study of Collective Efficacy and Collective Flow Among Workgroups. The Journal of Psychology, 148(4), 435-455. https://doi.org/10.1080/00223980.2013.806290

Sandstrom, G. M., \& Dunn, E. W. (2014). Social interactions and well-being: The surprising power of weak ties. Personality and Social Psychology Bulletin, 40(7), 910-922. https://doi. org/10.1177/0146167214529799

Sawyer, K. (2008). Group Genius: The Creative Power of Collaboration. New York: Basic Books.

Snyder, C. R., \& Lopez, S. J. (2010). Interceding to Prevent the Bad and Enhance the Good. In C. R. Snyder \& S. J. Lopez (Eds), Positive Psychology: The Scientific and Practical Explorations of Human Strengths (pp. 347-376). Thousand Oaks, CA: Sage Publications, Inc.

Sweetser, P., Johnson, D., \& Wyeth, P. (2012). Revisiting the GameFlow Model with Detailed Heuristics. Journal of Creative Technologies, 3.

Sweetser, P., \& Wyeth, P. (2005). GameFlow: a model for evaluating player enjoyment in games. Computers in Entertainment (CIE), 3(3), 1-24. https:/ / doi.org/10.1145/1077246.1077253

Szondy, M., \& Martos, T. (2014). A boldogság három arca: a Boldogság Orientáció Skála magyar változatának validálása. Mentálhigiéné és Pszichoszomatika, 15(3), 229-243. https://doi. org/10.1556/Mental.15.2014.3.5

Vargha, A., \& Borbély, A. (2016). Modern mintázatfeltáró módszerek alkalmazása a kétnyelvúség kutatásában. In Kissne Viszket, M., Puskas-Vajda, Z., Racz, J. \& Toth, V. (Szerk.), A pszichológiai tanácsadás perspektívái. Tisztelgó kötet Ritoók Magda 80. születésnapjára (pp. 173-186). Budapest: L'Harmattan.

Vargha, A., Torma, B., \& Bergman, L. R. (2015). ROPstat: A general statistical package useful for conducting person-oriented analysis. Journal for Person-Oriented Research, 1(1-2), 87-98. https://doi.org/10.17505/jpor.2015.09

Walker, C. J. (2010). Experiencing Flow: Is Doing it Together Better than Doing it Alone? The Journal of Positive Psychology, 5(1), 3-11. https://doi.org/10.1080/17439760903271116

Waterman, A. S., Schwartz, S. J., \& Conti, R. (2008). The Implications of Two Conceptions of Happiness (Hedonic Enjoyment and Eudaimonia) for the Understanding of Intrinsic Motivation. Journal of Happiness Studies, 9(1), 41-79. https://doi.org/10.1007/s10902-006-9020-7 


\title{
FLOW IN SOCIAL INTERACTIONS AND ITS RELATIONSHIP WITH THE ORIENTATIONS TO HAPPINESS
}

\author{
MAGYARÓDI, TÍMEA
}

Background and aims: Engaged (or flow-full) life is one of the orientations to happiness, part of the full life. Experiencing flow in a social interaction can enhance well-being, however this relationship has not been studied yet. The current study aims to reveal how social flow components relate to orientations to happiness.

Method: 1060 adult people participated in the online survey study - age: $M(S D)=26,67(10,76)$. They filled in the questionnaires anonymously: General Flow Description, General Flow Description in Social Interactions, Flow State Questionnaire, Flow Synchronization Questionnaire, Orientations to Happiness measure.

Results: We executed K-means cluster analysis with relocation to create four groups based on the hedonistic and eudaimonic orientations to happiness: eudaimonic, hedonistic groups, a group living an empty, and a group living a full life. The results suggest the differences between empty and full life in most of the flow-related variables (frequency of flow in solitary and social activities, quality of flow, components of flow synchronization), the effect sizes are moderate, the explained variance values by group memberships are around 5-13\%. Eudaimonic and hedonistic group members were not different from each other in the measured flow and flow synchronization components.

Conclusions: According to our results flow in a social interaction may contribute to the hedonistic (through the experience of positive emotions after flow) and eudaimonic (through development and growth, motivated activity) orientations to happiness as well, and it can be one necessary factor of full life.

Keywords: flow, flow synchronization, social interaction, full life, empty life, orientations to happiness

A cikk a Creative Commons Attribution 4.0 International License (https://creativecommons. org/licenses/by/4.0) feltételei szerint publikált Open Access közlemény, melynek szellemében a cikk bármilyen médiumban szabadon felhasználható, megosztható és újraközölhetô, feltéve, hogy az eredeti szerzô és a közlés helye, illetve a CC License linkje és az esetlegesen végrehajtott módosítások feltüntetésre kerülnek. (SID_1) 


\section{FÜGGELÉK}

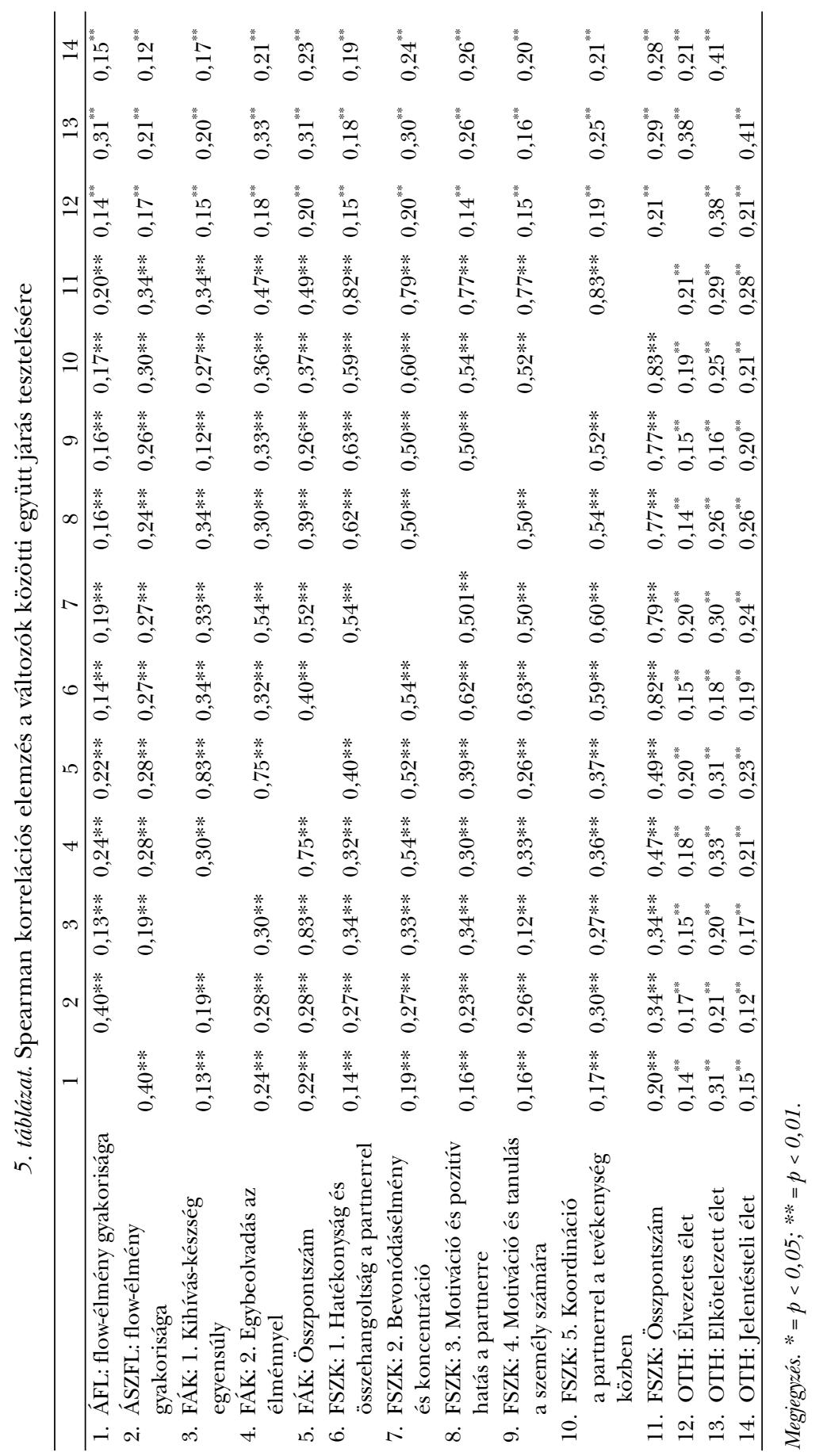

